\title{
ALTERITY AND OCCIDENTALISM IN FOURTEENTH-CENTURY ICELANDIC TEXTS: NARRATIVES OF TRAVEL, CONVERSION, AND DEHUMANIZATION
}

\author{
ARNGRÍMUR VÍDALÍN
}

\begin{abstract}
AN ICELANDIC MANUSCRIPT fragment from the turn of the fourteenth century, produced ca. 1290-1310, marks a turning point for recorded geographical knowledge in Iceland as the oldest extant treatise of its kind in Old Norse. ${ }^{1}$ It begins by stating "Sva er kallat sem prideild se iord," (it is said that the Earth is split into three continents), and is accompanied by a hemispherical mappa mundi as well as one of the three extant Icelandic maps of Jerusalem, including a topographical description of the city. ${ }^{2}$ Of particular interest is the manuscript's placement of Greenland to the north of Norway, with no mention of Iceland; it goes on to explain that, should one travel to the south from Greenland, one first finds the country of Helluland and then Vínland, "er sumir menn ètla at g[an]gi af Affrika" (which some suppose stretches out of Africa). ${ }^{3}$ These are the lands on the North American coast of the northern Atlantic which were encountered by Nordic voyagers around the year 1000, as narrated in Grænlendinga saga (Saga of the Greenlanders) and Eiriks saga rauða (Saga of Erik the Red). The latter of the two sagas was written down ca. 1302-1310, around the same time as the manuscript fragment, and is preserved in the compendium Hauksbók (Book of Haukr), which similarly contains a map of Jerusalem and a description of various countries. ${ }^{4}$ Also included in the Hauksbók is a geographical treatise under the heading "her segir fra marghattudum piodum" (here is told of manifold peoples). ${ }^{5}$ The ideas conveyed in this text are derived from the Natural History of Pliny the Elder (d. 79 CE) and the Etymologies of Bishop Isidore of Seville (560-636), both of which describe the monstrous races to be found on
\end{abstract}

I Reykjavík, Stofnun Árna Magnússonar (AM) 736 I quarto.

2 Simek, "Scandinavian World Maps," 537; Guðmundsdóttir, "Uppdráttur af Jórsalaborg," 96-97. See further Kedwards, The Mappae Mundi of Medieval Iceland. A complete transcription of the mappa mundi's text may be found in Simek, Altnordische Kosmographie, 419-24.

3 Simek, Altnordische Kosmographie, 429-32; Alfræði íslenzk I, 8-12. This information is entirely lacking in the mappa mundi, which does not even mention Vínland.

4 Reykjavík, AM 371 quarto; Copenhagen, Arnamagnæan Manuscript Collection 544 quarto and 675 quarto.

5 Hauksbók, 165. 
the peripheries of the world. The fragmentary geographical treatise thus strongly implies that Vínland and its peoples belong to the same periphery as West Africa. The sagas also depict Vínland and its hinterland as inhabited by Plinian Sciopodes (folk who shield themselves from the sun with a single "shade-foot") as well as the indigenous people whom the Norse called skrælingar, a term of uncertain meaning which may refer to their skin colour or clothing.

The inclusion of both mythical and actual peoples in the ethnography of the sagas speaks volumes about their authors' learning while also revealing the development of racialized categories applied to contemporary Others. ${ }^{6}$ At the same time, the manuscript fragment's borrowing from that same ethnographic tradition, plus its omission of Iceland from the periphery it describes, suggests an allied agenda. ${ }^{7}$ Though much of Old Norse literature springs from a long oral tradition of storytelling, it was only at the turn of the fourteenth century that classical geographic and ethnographic canons became fused together in such manuscripts, with medieval Icelanders' extraordinary knowledge of the lands to the west of northern Europe, derived from the narratives of their unprecedented voyages to America. This local initiative, I will argue, also participated in an older European narrative tradition of "travels to the East" and the marvels to be witnessed there: the spike in the creation of these vernacular travel narratives coincides with an increase in the circulation of texts describing the Holy Land and the Indies (Old Norse: Indialond). ${ }^{8}$ On the one hand, this is indicative of increased interest in exotic locations and creatures: a trend evident throughout Europe in the fourteenth century. On the other hand, travel narratives are always narratives of the self, which cannot exist without the differences of the other. ${ }^{9}$ So how do these texts encode the negotiation of Icelandic identity in this pivotal era? While a tendency toward dehumanization of the Other abounds in medieval literature, in these texts it serves the specific function of bringing Iceland closer to the cultural and religious centre of Europe, by including Iceland within the boundaries of civilization and by making monsters of the peoples further west, in newfound America. ${ }^{10}$ This agenda can be observed through the Old Norse travel narratives' contrasting perceptions of the far East and the far West.

6 See, e.g., Friedman, Monstrous Races, 8.

7 Vídalín, "From the Inside Out."

8 Jakobsson, “On the Road to Paradise,” 936.

9 Williamsen, "Boundaries of Difference," 454.

10 I have previously written on black Africans (blámenn) as subject of proto-racism in Old Norse literature: Vídalín, "Demons, Muslims, Wrestling-Champions" and "The Man Who Seemed Like a Troll." I am indebted (among others) to Merkelbach and Knight, Margins, Monsters, Deviants; Jakobsson and Mayburd, Paranormal Encounters; Heng, The Invention of Race; Eliav-Feldon, Isaac, and Ziegler, The Origins of Racism; Isaac, The Invention of Racism; Smith, Less than Human; Mallon, The Construction of Human Kinds. 


\section{Geographies of Alterity}

The ideas of identity and alterity that inform the Vínland sagas are also reflected in the Leiðarvísir (Travel Guide), an itinerary preserved in another fourteenth-century manuscript which I have named the Narfeyrarbók, because it was written in 1387 by the priest Óláfr Ormsson of Geirrøðareyri (present-day Narfeyri) in Snæfellsnes, the westernmost peninsula of Iceland. ${ }^{11}$ Previous scholars have assumed this text to have been composed between 1154-1159, under the supervision of Nikulás Bergsson, abbot of the Benedictine monastery at Munkapverá. This misdating derives from a colophon stating that "this itinerary and information on cities is written under the direction of the abbot Nicholas, who was both wise and famous, of good memory and much wisdom, gave good counsel and spoke truthfully, and here concludes this narrative."12 But Tommaso Marani has recently shown that much information included in the Leiðarvísir is incompatible with a twelfth-century dating and thus with abbot Nikulás's authorship. ${ }^{13}$ There are several additional reasons to doubt Nikulás's involvement, and even if Óláfr Ormsson was indebted to an older text, he will henceforth be considered the author of this work. ${ }^{14}$

Although the itinerarium is an ancient genre, the Leiðarvísir is unique in describing the route from Iceland to Rome and Jerusalem, and not least in its remarkable blending of Christian lore with Germanic myth. We thus encounter Gnitaheiði, the home of the dragon Fáfnir and his hoard of gold, adjacent to a hospice for pilgrims in Piacenza; the snake pit where Gunnarr Gjúkason was killed; ${ }^{15}$ and the resting places of saints. ${ }^{16}$ The Leiðarvísir also features a purportedly accurate astronomical observation which has no known parallel in any other source: "By [the river] Jordan, should one lie prostrate on a flat field and raise one's knee, place the fist upon the knee and raise a thumb up from the fist, then a guiding star will be seen at that height in the sky and no higher." ${ }^{17}$ However, the Leiðarvísir bears

I I Reykjavík AM 194 octavo. I am currently in the process of editing the text of this manuscript.

12 Alfræði íslenzk I, 23: "Leidarvisir sea ok borga-skipan ok allr pessi frodleikr er ritinn ath fyrir-sogn Nicholas abota, er bèdi var vitr ok vidfregr, minnigr og margfrodr, rádvis ok rettordr, ok lykr par pessi frasogn."

13 Marani, "Leiðarvísir," 42-47.

14 Vídalín, "Óláfr Ormsson’s Leiðarvísir."

15 “Völsunga saga," 81-83.

16 Lönnroth, "A Road Paved with Legends."

17 Marani, Leiðarvísir, 41: “Ut vid Iordan, ef madr liggr opinn á slettum velli ok setr kne sitt upp ok hnefa á ofan ok reisir pumal-fingr af hnefanum upp, pa er leiparstiarna par yfir ath sea iafn-ha en eigi hèra." See Alfræði íslenzk I, 23. 
no indication of being an eyewitness account; its author did not, in all likelihood, travel this road to Jerusalem. ${ }^{18}$

What is particularly striking about the Leiðarvisir is the manuscript context in which it is preserved: buttressed between Óláfr Ormsson's copy of the fragmentary geographical treatise (with which we began) and a description of the resting places of saints which he apparently copied from the Hauksbók. Following the latter is a catalogue of the world's monstrous peoples not copied from any known manuscript, but clearly derived from Pliny. The Narfeyrarbók thus includes information from two older Old Norse compendia while juxtaposing Pliny's monsters with an itinerary to Jerusalem, on the route to which mythological way markers and other paranormal phenomena are used to familiarize an Icelandic audience with exotic sites. Through this mode of viewing the Other, this text-like the earlier manuscripts of the fourteenth century-reflects a sense of self shared by the author and intended audience, articulating and challenging their underlying ideologies and cultural norms. In the words of Elizabeth Williamsen, "The 'self' of the travel narrative is removed from its familiar context and placed into strange or even dangerous situations that may call for a rethinking of assumptions, whether about the foreign culture or about its own."19 The result is an enlarged worldview which not only allows for the coexistence of pagan monsters within a Christian framework, but also aims to renegotiate their relationship to one another on the medieval globe. ${ }^{20}$

\section{Icelandic Travels to the East: Mission Accomplished}

We have now established that Old Norse geographical texts had one foot in classical learning and another in the mainstream Christian theology of the later Middle Ages. ${ }^{21}$ In this section and the next, we will look at Old Norse narratives of travel to the East and West, respectively, in order to show how differently they treat the encounter between Scandinavians and foreigners on the peripheries of Orient and Occident. I will show that travels eastward serve to Christianize legendary Scandinavian travellers and to normalize their relationships with courteous

18 Marani, Leiðarvísir, 233-34.

19 Williamsen, "Boundaries of Difference," 453. See also Dinzelbacher, "Die mittelalterliche Allegorie"; Zumthor, "Medieval Travel Narrative."

20 This was customary of Christian geographical treatises, cf. Augustine's The City of God, 5: 40-49 (XVI: 8).

2I Constricting modern assumptions of genre have at times dictated against comparing learned writings to sagas; genre continues to be a hotly debated topic within Old Norse scholarship. See Quinn et al., "Interrogating Genre in the Fornaldarsögur: Round-Table Discussion." 
Europeans and other civilized folk. By contrast, the travels westward made by previous generations of Nordic people, represented as mostly Christian, puts them in the path of natives represented as monstrously uncivilized, who thwart their attempts to conquer this new frontier.

The few Nordic sources describing travels to Jerusalem and beyond, all written in the fourteenth and fifteenth centuries, include an Old Danish translation of the Old French Travels of Sir John Mandeville (Le Livre des merveilles, ca. 1350), dating to around 1459 or perhaps earlier. ${ }^{22}$ The three most prominent Icelandic tales of travel to the East all involve young men who set out on pious journeys to the Holy Land, all of whom share the moniker víðforli, "the Far-Travelled."23 These sagas are also set during the tumultuous events surrounding the conversion of Scandinavia and Iceland, and their heroes become the pioneers who engineered that conversion. All of them therefore share a common Christian ideology, making claims to the sanctifying effects of travels to the East while promising salvation for those of true faith at home.

The first, and the least detailed in its depictions of the East, is Porvalds páttr vífforla (The Tale of Thorvald the Far-Travelled). It centres on the attempts of the king's man, Porvaldr Koðránsson, to Christianize Iceland along with the Saxon bishop Friðrekr (not an historical figure). ${ }^{24}$ After failing in his mission and falling out of favour with the bishop due to his violent outbursts, Porvaldr travels to Jerusalem and Constantinople, where he is welcomed by the emperor himself and subsequently made overlord of all the kings of Rus' and Byzantium. He then founds a monastery, where he lives out the rest of his life. ${ }^{25}$ Not much is said of Porvaldr's stay in the Holy Land, and he does not seem to have gone as far to the East as the other "far-travelled" saga heroes. It also seems unlikely that this narrative springs from the same tradition as the others; its main focus is Porvaldr's failed mission in Iceland, so that his exotic journey reads like an act of expiation for his sins.

The second narrative, Eiríks saga víðforla (The Saga of Erik the Far-Travelled), is more replete with descriptions of the East. It is extant in the Flateyjarbók, a giant

22 Mandevilles rejse, xlii-lxxii.

23 There are others, such as the travels of Haraldr Sigurðsson Harðráði in southeastern Europe and his stint in the Varangian Guard, and the travels of Sigurðr Magnússon Jórsalafari to Jerusalem, where he bathes in the river Jordan and receives a piece of the True Cross. Both these stories are recounted as part of larger kings' sagas, such as the Heimskringla and Morkinskinna. For Sigurðr Jórsalafari's trip to Jerusalem, in particular, see Morkinskinna, 87-95.

24 Biskupasögur I, clxiv-clxxx. Then again, we have few ways of verifying the existence of many characters in Old Norse literature.

25 "Porvalds páttr víðfọla I," 88-89. In the B-version of Porvalds páttr it is not stated that he travelled to Jerusalem: "Porvalds páttr víðfọrla II," 98-100. 
manuscript compendium compiled between 1387 and 1394, and is closely related to Yngvars saga víðforla (The Saga of Yngvarr the Far-Travelled, discussed below). It also owes much to the Elucidarium, an eleventh-century theological summa, and De imagine mundi, both by Honorius Augustodunensis; as well as to the Visio Tnugdali, a twelfth-century Latin reworking of a Middle Irish visionary text. ${ }^{26}$ Young Eiríkr, son of the legendary Prándr, whom the saga claims as the first "king of Trondheim," vows to travel the world to find the Elysian Fields (Ódáinsakr) or the terrestrial Paradise (jörð lifandi manna eða Paradisum), ${ }^{27}$ which in his mind are the same place. On the way there, Eiríkr and his crew are welcomed by the emperor in Constantinople. During his tenure at the court, Eiríkr has didactic conversations with the emperor on various matters pertaining to his quest, all directly derived from the Elucidarium, which existed in Old Norse translation as early as ca. $1200 .^{28}$ (There is a similar conversation in the Norwegian Konungs skuggsiá, ca. 1250, in which the son asks the father about exotic lands and their monstrous fauna. $)^{29}$ When Eiríkr asks which country is to be found in the farthest corner of the southern hemisphere, the emperor identifies it as "India": a common term in Old Norse for a great landmass extending, in some accounts, both east and far south into Africa. ${ }^{30}$

As Eiríkr and the audience of his saga knew, this was a land of monsters. In 1302-1310, when the Icelandic lawspeaker Haukr Erlendsson produced his impressive summary of world history and knowledge-one of the key texts introduced in my first paragraph-many of this world's inhabitants were of Plinian stock. ${ }^{31}$ The most detailed of related geographical treatises, found in the Icelandic biblical compilation Stjórn (ca. 1350), represents Asia and Africa as almost exclusively inhabited by monstrous peoples such as blemmyae, panotii, sciopodes, troglodytes, cyclopes, and the like. ${ }^{32}$ The manuscript containing the Leiðarvísir (described above, and containing excerpts from the Hauksbók) also

26 Rowe, The Development of Flateyjarbók, 153-54. Known in Old Norse translation as Duggals leizla. See Wellendorf, Kristelig visionslitteratur i norrøn tradition, 200-246; Duggals leiðsla.

27 "Eireks saga víðförla," 449.

28 [Honorius Augustodunensis], Elucidarius, xxvi-xxvii. For more detail, see Elucidarius, xxviii-lxxix.

29 Konungs skuggsiá, e.g., 27-29. See also Vídalín, "Ideals of Christian Kingship," 129-38.

30 This is discussed in greater detail in Vídalín, "From the Inside Out”; Vídalín, Skuggsjá sjálfsins, 65-120.

3I Hauksbók, 153-56, 165-67.

32 Stjórn, 100-151. 
has a description of the monstrous peoples of India, including blemmyae (headless men) or lamnies, as they are called in this particular manuscript. ${ }^{33}$ So when Eiríkr asks the emperor about the "yfirbragði pjóða ok grein landa" (physical features of peoples and the demarcation of lands) and "frá mönnum undarligum ok búningi peira ok siðum margra pjóða, frá höggormum ok flugdrekum ok alls kyns dýrum ok fuglum, frá gnótt gulls ok gimsteina" (of strange men and their clothing and the customs of many peoples, of serpents and flying dragons and all kinds of animals and birds, of abundances of gold and gemstones), ${ }^{34}$ these questions and their answers were already familiar. ${ }^{35}$ As Sverrir Jakobsson has noted, the "insertion of a geographical description of this sort into a víðförla saga is a reminder that the world-view of these narratives was not distinct from what can be found in more learned works." 36

In the end, Eiríkr manages to find the closest thing to Paradise, becoming a kind of Christ figure presaging the conversion of Scandinavia. Having learnt from the emperor that Paradise is beyond the farthermost lands of India, Eiríkr and his men are all christened before making the journey. In the East, upon attempting to find the source of a great river which Eiríkr deduces to be the Phison, they come across a terrifying dragon with its mouth wide open, very much akin to a Hellmouth. Undaunted by his comrades' warning, Eiríkr runs into the dragon's mouth along with one of his men, finding that it leads not to Hell but to the terrestrial Paradise, filled with the wondrous odours of flowers and streams of honey, a land where the sun never sets. ${ }^{37}$ An angel appears to announce that this wonderful place is but a desert in comparison to the heavenly Paradise; as recompense for his arduous journey, Eiríkr is offered the choice of staying in the quasi-Paradise or returning home. When he makes the second choice, the angel tells him that the pagan Scandinavians will soon be freed from heresy and sends Eiríkr home to tell of his miraculous travels. ${ }^{38}$ Ten years after his return to Norway, Eiríkr is summoned

33 Alfræði íslenzk I, 34-36.

34 “Eireks saga víðförla," 449-50.

35 This is shown, e.g., on the Hereford mappa mundi, where the Carimaspi battle gryphons for emeralds: see Kline, Maps of Medieval Thought, 141-64.

36 Jakobsson, "On the Road to Paradise," 938.

37 This is reminiscent of the Promised Land of the Saints from the Old Irish Voyage of Saint Brendan which, just as it is "ripe with fruit, so shall it remain always without any shadow of night. For its light is Christ." See The Voyage of Saint Brendan, 69. Brendan's voyage was translated into Old Norse and a fragment is now extant in a thirteenth-century manuscript written in Norway (see Tómasson, "Ferðir pessa heims og annars," 34-35), so the story was likely known in Iceland.

38 "Eireks saga víðförla," 453. 
by the spirit of God and the saga explains how Eiríkr overcame his pagan roots and escaped punishment for his sins thanks to his faith. Thus Eiríkr víðfǫrli is transformed from a pagan voyager to a Christian soldier on the verge of sainthood, a man who sought out Paradise but rejected the opportunity to stay there in favour of becoming a missionary in Norway.

Finally, Yngvars saga víðforla tells a similar tale of the young prince, Yngvarr, who seeks a kingdom for himself in faraway lands. His saga could be said to expand on the narrative of Eiríkr, further emphasizing geographical knowledge, encyclopedic learning, and the continuity of the Plinian tradition. Yngvarr sails to Kievan Rus' (Garðaríki) and stays three years at the court of the King Jarizleifr (Yaroslav the Wise, ca. 978-1054), studying many languages. There, he learns of a great river east of Russia, to which he leads an expedition. Yngvarr's journey is much more perilous than Eiríkr's. The men encounter strange animals, an "ógurlegr risi" (a terrible giant), and a pile of gold covered in serpents. One man accidentally awakens a serpent by reaching for a golden ring, and eventually the whole pile is writhing. The lead serpent, Jakúlus, is another familiar figure from Pliny, its name derived from its behaviour of throwing itself (iactare) down from trees. ${ }^{39}$ Jakúlus is also mentioned in a list of serpents found in the Narfeyrarbók, the manuscript containing the Leiðarvísir. ${ }^{40}$ When Jakúlus is killed, a horrible stench emanating from the carcass kills six men. Foul smells were often associated with the demonic in the Middle Ages and not least in Old Norse literature. ${ }^{41}$ The primordial guise of Satan was, after all, a serpent. ${ }^{42}$

The immoderate desire for gold exhibited by the protagonist's cohort is thus clearly condemned and frequently leads to death, suggesting that the saga equates the desire for worldly wealth with paganism. Instead, the path to religious enlightenment does not yield material gains, as the saga of Eiríkr víðforli had demonstrated, by having him forego the pleasures of Paradise. This is further illustrated in a later passage in which Yngvarr and his men kill a fearsome giant and then bring one of his enormous feet with them, salting it for preservation as was customary in medieval Scandinavia. Here, they seem to commit an act almost as monstrous as the giant, whose sapient, humanoid corpse they mutilate to preserve parts as food-thereby mirroring trolls' legendary treatment of their human prey. ${ }^{43}$

39 Isidore, The Etymologies of Isidore of Seville, 257.

40 Alfræði íslenzk I, 39.

4 I Jakobsson, “Íslenskir draugar," 198.

42 Russell, Lucifer, 67.

43 "Yngvars saga víðförla," 376-77. Cf. "Ketils saga hœngs," 249-50. See also Vídalín, "Er pat illt," 191-202; Friedman, Monstrous Races, 26-29. 
They later find a suitable application for the salted giant's foot, which they use to bait a trap for an enormous dragon in order to steal its great mound of gold. They manage to get away with some of it before the dragon's return, and Yngvarr warns his men to not look back. The few who do not comply witness the dragon performing some strange ritual on top of its gold pile, the sight of which kills the onlookers. ${ }^{44}$

Eventually, Yngvarr is offered the kingship of Citopolis ${ }^{45}$ by the queen Silkisif, who turns out to speak several languages: not only Latin, Greek, and German, but even Norse, which is not usually within the range of cosmopolitan languages featured in medieval European romance literature. She also offers him her own hand in marriage, yet Yngvarr is determined to find the source of the river before accepting her and the throne. He travels onward to Heliopolis in Syria, ${ }^{46}$ where he stays with King Jólfr. Much like Eiríkr, Yngvarr is devoted to learning as much as possible from the king, including that the river he seeks leads to the Red Sea and then to a place which is called "the End of the World." ${ }^{47}$ (This didactic passage illustrates how much Yngvars saga owes not only to the Elucidarium, but also to the Konungs skuggsiá, which exhibits a particular interest in such strange places. $)^{48}$ At this point, the travellers are confronted by a large group of strange women who enter their camp at night. The one in charge attempts to bunk with Yngvarr, who phallically stabs her in the vagina with a knife. His men try to follow suit, although a few "stóðust [ei] peira blíðlæti af djöfulligri fjölkynngi ok lágu hjá peim" (could not resist the pleasure of their demonic magic and lay with them) ${ }^{49}$ The morning after, eighteen of Yngvarr's men have been killed by intercourse with the demonic women. Soon after, Yngvarr himself succumbs to a fatal disease along with most of his men; it is uncertain whether this is meant to be the same disease as that carried by the demonic women. Before his death, he asks that his body be brought back to Sweden and buried in a church, his possessions divided into three parts: one for the churches and clerics, a second for the poor, a third for his father and son. According to the saga, Yngvarr died in the year 1040 at the age of twenty-five, eleven years after the fall of St. Óláfr Haraldsson, king of Norway.

Yngvarr's exploits turn out to be a failure. He travelled far but did not succeed in his mission, and his troop of men either succumbed to the lust for gold or their

44 “Yngvars saga víðförla," 378-79.

45 Most certainly Scythopolis, or Beit She'an in the North District of Israel.

46 Most likely Baalbek in Lebanon.

47 "Yngvars saga víðförla," 375-76. For differing interpretations of this episode, see Lönnroth, "From History to Myth," 100-114; Antonsson, "Salvation and Early Saga Writing."

48 Cf. Vídalín, "Ideals of Christian Kingship."

49 “Yngvars saga víðförla," 381. 
lust for women, suggesting that the devil himself played a hand in the fate of this expedition. The saga then continues with the exploits of Yngvarr's son Sveinn, who is adamant that he will finish his father's work and in fact fares much better. In addition to battling with strangers and monsters, he and his men meet heathens with whom they trade. When one of Sveinn's men wants to rescind an agreement with one of the heathens, it quickly precipitates a battle. (As we will see, a similar scene is to be found in the two sagas of the Norsemen's travels to the West, in which their attempts at commerce with Native Americans turn sour.) Another encounter with heathens who offer to trade leads to an invitation to feasting; but when Sveinn's men cross themselves before the meal, the heathens become furious and attack them. ${ }^{50}$ Farther down the river, they come across a magical, possibly demonic, army which resembles the Crane People of the German epic Herzog Ernst (ca. 1180), ${ }^{51}$ ultimately derived from Pliny's Natural History. The author's debt to Pliny is further illustrated by our heroes' confrontation with a strange animal they do not recognize-although the author does. ${ }^{52}$ The animal's description becomes a kind of guessing game between audience and author, since the answer is never divulged. And while the saga's audience would never have seen such a beast, they might have been familiar with the similar description of an elephant to be found both in the twelfth-century Icelandic Physiologus and in the aforementioned Stjórn, where elephants are said to be few in Africa (due to the prevalence of dragons) but plentiful in India. ${ }^{53}$ For those in the know, this would signal that Sveinn and company have arrived in the East.

The Christian agenda of the entire narrative is emphasized at the saga's closing, when Queen Silkisif orders that a church be raised at Citopolis and sanctified in the name of the holy Yngvarr víðforli. The bishop is reluctant, since Yngvarr has not produced any miracles since his death and thus does not qualify as a saint. Silkisif argues that perseverance in the true faith is more worthy in the eyes of God than miracles; the bishop astonishingly agrees and sanctifies the building in the name of Yngvarr. ${ }^{54}$ The story then concludes with a great register of authorities verifying its authenticity, including a direct quotation in Latin from a certain Gesta Saxonum, which seems to be the Gesta Hammaburgensis ecclesiae pontificum by Adam of Bremen. ${ }^{55}$ Given the existence of rune carvings that affirm the travels of

50 "Yngvars saga víðförla," 388-89.

5 I "Yngvars saga víðförla," 386-67; Strickland, "Sartorial Monsters of Herzog Ernst," 130-64.

52 “Yngvars saga víðförla," 387.

53 Stjórn, 145.

54 "Yngvars saga víðförla," 391-92.

55 Jensson, “Were the Earliest Fornaldarsögur Written in Latin?", 83. 
Yngvarr víðfǫrli, a Nordic audience of the fourteenth century would already have been familiar with the legend. ${ }^{56}$

In sum, the narrative travels of Norsemen to the East share similar Christian quests for salvation and identity within a wider and exotic world. Porvaldr, Eiríkr, Yngvarr, and Sveinn are restless young men without a clear purpose in life; travelling east brings them both spiritually and geographically closer to God. Although failing as a missionary, Porvaldr overcomes the burden of his pagan upbringing by travelling east and becoming a hermit at home. Eiríkr finds the terrestrial Paradise and returns to preach Christianity to his kinsmen in Norway. Yngvarr wishes to find the origins of a river in Asia, perhaps believing that it may lead to Paradise, but loses his life due to his companions' greed and lust. Yet his son Sveinn finishes his work and returns to his new kingdom in Russia, while saintly glory is restored to his father through the agency of Queen Silkisif. All of the víðforlasögur are therefore narratives of religious transformation, of overcoming temporal limitations for the love of God and the benefit of their own people. As Katja Schulz notes, Yngvars saga reflects to a high degree the encyclopedic traditions of the Middle Ages while still remaining true to local tradition. ${ }^{57}$ The moral of these sagas, as in the Leiðarvísir and their companion texts, is that salvation is found in the East.

\section{Icelandic Travels to the West: Mission Impossible}

In the narratives describing travels to the West, Christian heroes also encounter adversaries in the form of dehumanized Others: in this case, the indigenous peoples of North America. Both Eiríks saga rauða (1302-1310) and narratives from Óláfs saga Tryggvasonar in Flateyjarbók (1387-1394, collectively known as the Grænlendinga saga) centre on the colonization of Greenland by Eiríkr the Red and subsequent travels to Newfoundland (Canada) undertaken by his sons Leifr and Porvaldr, among others. ${ }^{58}$ Often called the Vínland sagas, these may also be counted among víðforla, "Far-Travelled," sagas. But when travelling east, as we have seen, heroes meet with noble, knowledgeable, and courtly people who can enlighten them about the dangerous frontier ahead and the monsters that inhabit it. When travelling west, the protagonists meet no such people, as they themselves

56 Lönnroth, "Ingvar Stones."

57 Schulz, Riesen, 244-45.

58 Archaeological evidence indicates the presence of Nordic travellers in North America around the year 1000: see, e.g., Sigurðsson, Túlkun Íslendingasagna, 251-300; Kristjánsson, "Falling into Vínland," 354-404; Porláksson, "Vínland Sagas," 63-77. On the sagas themselves, see Jochens, “The Western," 78-87; Halldórsson, “The Vínland Sagas," 39-51. 
are the first Europeans to brave that new frontier and can only learn about it through direct experience. In the end, all their attempts at colonization fail, with especially disastrous results in Eiríks saga rauða. They do, however, set their mark on the newfound lands by establishing a great outpost of Christianity in Greenland.

In the sagas, Vínland is depicted as an excellent land where livestock does not need hay in winter because the earth never freezes and the grass remains good all year round. Indeed, it is a veritable land of milk and honey reminiscent of the Elysian Fields or Paradise of Eiríks saga víðforla, also described in the Flateyjarbók. Vínland is also a land of grapes, reminiscent of the Island of Grapes in The Voyage of Saint Brendan, where Brendan and his fellow travellers feed on grapes for forty days before embarking and "bringing with them as much of the fruits as their boat could carry."59 This connection to the Irish legend is even hinted at in Eiríks saga rauða, which mentions a land called Hvítramannaland (The Land of White Men) where men (presumably Irish monks) wear white clothing, carry great staffs, and yell loudly in the practice of their religion. ${ }^{60}$

Yet the heroes who settle Greenland, the sagas imply, never counted on meeting anyone there. And when Leifr's brother Porvaldr sets out to explore Vínland and to find a suitable place for a farmstead, he and his men are shocked to find three piles in the sand which turn out to be skin boats (húðkeipar), each with three men lying beneath it. They attempt to seize the men; one gets away on his boat, the rest are killed. Then Porvaldr and his men look inland toward the fjord and see a settlement there. Suddenly, gripped with drowsiness, they fall asleep and are awakened by a voice telling them to leave the country immediately if they wish to survive. They find themselves under siege by a legion of skin boats, a pars pro toto description of the strange-skinned men, skrælingar, who steer them. Already, the narrative has taken a dehumanizing turn as Porvaldr and his men defend themselves and retreat.

Physical and cultural difference have always been employed to draw a line of demarcation between self and Other: as when foreign nations are equated with their diet, ${ }^{61}$ whether the Plinian ichtiophagi (fish-eaters) or the troll-like Finns in the sagas of the heroes of Hrafnista, who are ridiculed for their love of butter; ${ }^{62}$ or with their place of habitation, such as the troglodytes (cave-dwellers). Hence the inhabitants of Vínland are rendered monstrous and reduced to the skin boats

59 “Grœnlendinga saga," 248-54; The Voyage of Saint Brendan, 47.

60 “Eiríks saga rauða," 233-34.

6 I Friedman, Monstrous Races, 26-29.

62 Colloquially known as the Hrafnistumannasögur: Vídalín, “Er pat illt,” 191-202. 
they sail and sleep under. ${ }^{63}$ And because this was a people not accounted for in any learned source accessible to Scandinavians, ${ }^{64}$ the Icelanders placed Vínland and its peoples within the Plinian ethnography most familiar to them. It is therefore impossible to tell whether the Old Norse word skrælingi refers to Native Americans, the Inuit people, or any hitherto unknown native people. The name skrælingar clearly implies something about skin, or skin clothing. ${ }^{65}$ The word was in use prior to the writing of the Vínland sagas, for example in the Íslendingabók, likely written between 1122 and 1133 (extant in a seventeenth-century copy), and in the Historia Norwegiae, thought to have been written ca. 1150-1200 (extant in a copy from 1344). ${ }^{66}$

Here, it should also be kept in mind that the protagonists of the Vínland sagas, excluding Eiríkr the Red, are represented as newly converted Christians and that the narrative is tailored toward a fourteenth-century Christian audience. The skrælingar, by contrast, are monstrous people who live on the outermost edges of the world and may be killed on sight, for they are also skilled illusionists and sorcerers, much like the Finns or Sámi were reputed to be. ${ }^{67}$ They do not know how to barter with the Christians or how to use European weaponry; they can only be made civilized if christened, as the heroes find out at the end of Eiríks saga rauða, when they baptize two skræling children who are taught the Nordic language-reminiscent of a tale in the Cursor mundi, in which King David blesses four pitch-black Saracens whose skin turns milk white in consequence. ${ }^{68}$ And yet the Norsemen have no intention of converting the skrælingar; they would rather be rid of them.

Moreover, unlike the cosmopolitan elites of the eastern travel narratives, the skrælingar and the Scandinavians cannot understand each others' languagesreminiscent of the failed encounter with the strange heathens of Yngvars saga. ${ }^{69}$

63 In Örvar-Odds saga, the Irish are dehumanized in a similar fashion for living in holes in the ground. The hero Oddr finds women in a house in the ground and denigrates them as trolls: "Örvar-Odds saga," 313.

64 Jakobsson, "Black Men," 88-89.

65 The verb skræla means "to peel" in modern Icelandic. Although this verb is not found in Old Norse texts, to my knowledge, the Old Norse noun skrælingi may mean someone who skins, someone who wears skins, or someone whose skin seems strange or exotic: the synecdoche clearly refers to skin. The term skrælingi has been widely discussed in scholarship with no real consensus as to its meaning, e.g., Gade, "Skrællinger," 715-18; Thalbitzer, Fra Grønlandsforskningens, 14.

66 Jakobsson, “Black Men," 90, 92-94.

67 Jakobsson, “Black Men," 94-99; Pálsson, Úr landnorðri, 14-27.

68 Arjana, Muslims in the Western Imagination, 29.

69 Jakobsson, "Black Men," 90-91 and “On the Road to Paradise," 940. 
Their first attempt at communication involves the trading of skins for farm goods and, although this exchange is made without any real problems, the skrælingar are described as being so primitive that they even fear the lowing of a bull. In Eiríks saga rauða, the foolishness of the natives is emphasized when Porfinnr and his men have little left to sell and resort to cutting what wares they have into smaller and smaller pieces, for which the skrælingar pay an equal amount, or even more. Another misunderstanding occurs in Grœnlendinga saga, when the skrælingar return at a later time for a second exchange. Guðríðr Porbjarnardóttir, the saga's main female protagonist, is surprised when a short, pale woman-“mjög eygð svá at eigi hafði jafnmikil augu sét í einum mannshausi" (with eyes so big that she had never seen eyes like that in any human head)-enters her abode. ${ }^{70}$ When Guðríðr asks her name, she replies: "My name is Guðríðr, what is your name?" Guðríðr replies in the same way and then reaches out to her; at that exact moment, she hears a great crack: the strange Guðríðr is gone and a skrælingr has been killed by one of the servants of Porfinnr Karlsefni because he had attempted to grab one of their weapons. The skrælingar run away, leaving their goods, and it is said that no one saw the peculiar woman except for Guðríðr. ${ }^{71}$

This episode runs parallel to the scene in Yngvars saga vífforla when, after a failed barter, one of Yngvarr's companions hacks a heathen in two and a large battle takes place in which many more heathens are killed. In the Gronlendinga saga, a battle between natives and newcomers follows the strange encounter with Guðríðr and her alter ego. Porfinnr Karlsefni has his men lead the aforementioned bull into battle, since the skrælingar are so afraid of it. Again, there are moments of fleeting familiarity juxtaposed with violent misunderstandings: on the one hand, a single man in the enemy front line seems strong and handsome to Porfinnr, and so he deduces that this person must be their leader; on the other, the skrælingar's primitive nature is revealed when one picks up an axe and, after pondering it for a bit, wields it and strikes his comrade, killing him. The effect of the weapon shocks the unwitting murderer, who throws it out to sea and then flees with his men into the woods. ${ }^{72}$ As in Katja Schulz's analysis of the giants of Yngvars saga, the skrælingar are portrayed as unfathomable, inhuman beings. ${ }^{73}$ When Freydís

70 The meaning of the phrase "mjög eygð” (literally: very eyed) is ambiguous.

7I "Grœnlendinga saga," 262-64. What this evidently supernatural encounter is meant to convey in the narrative has never been resolved by scholarship, though not for lack of suggestions. See, e.g., Almqvist, "My Name Is Guðríðr," 15-30; Larrington, “'Undruðusk pá, sem fyrir var'," 105-6.

72 "Grœnlendinga saga," 263-64.

73 Schulz, Riesen, 244. 
Eiríksdóttir, Leifr's sister, finds herself alone during a battle and surrounded by the skrælingar, she reaches for a sword, pulls her breast from out under her clothes, and aggressively bashes the blunt side of the sword against it, causing terror amongst the skrælingar who flee back to their boats. ${ }^{74}$ Even the word used for the sounds made by the skrælingar, "ýla," is a wild shriek associated with animals, particularly birds.

The extent of the inhuman alterity assigned to the skrælingar can be thrown into relief by comparing these strange natives to the Scottish duo, Haki and Hekja, whom Eiríks saga rauða describes as "swifter than animals" and dressed in strange and revealing outfits. When unfamiliar territories need to be assessed, they are released like dogs into the newfound land to inspect it. Their primitive and skimpy attire is itself a mark of the beastly: in Gríms saga loðinkinna, a tale of a young man whose bride goes missing, trolls are dressed "í stuttum og skörpum skinnstökkum bæði. Gerla sá hann, hversu pau voru í sköpun bæði í millum fótanna” (in short and uneven skin suits, both of them. He could clearly see how they were shaped between the legs). ${ }^{75}$ The animalistic qualities of Haki and Hekja would also be associated with the narrative of Hrafna-Flóki who, according to the Icelandic Landnámabók (Book of Settlements), employed ravens to help him locate Iceland in the ninth century. ${ }^{76}$ Thus Haki and Hekja return, like the last of Flóki's ravens, with proof of the land's bounty: a cluster of grapes and wheatgrass. ${ }^{77}$ Although the Scots were people much less foreign to the Scandinavians, and people with whom they could converse, they are still described and deployed as birds or hunting-dogs. If even Scots could be considered less than human, then the dark-skinned skrælingar who lived underground and whose strange language made them effectively mute could be perceived as monstrous: both dangerous and disposable.

When Porfinnr and company decide to abandon Vínland, they sail north along the coast. On their way, they find five skrælingar sleeping and seemingly banished from their society. In an unexplained act of retribution for their failure to settle the land, the Norse kill them in their sleep: an act of blatant murder in Old Norse society, here seemingly justified by the assumed inhumanity of the murdered. Making their way further north, they come across a sciopod (einfæetingr) who shoots an arrow into the small intestine of Porvaldr Eiríksson, killing him. Porfinnr Karlsefni and his men attempt to retaliate against another einfetingr, but they cannot catch it.

74 “Eiríks saga rauða," 229.

75 “Gríms saga loðinkinna," 270-73.

76 “Landnámabók," 36-39.

77 “Eiríks saga rauða," 223. 
When they come in sight of Einfætingaland, the land of the sciopodes, they decide it is too dangerous to investigate any further. ${ }^{78}$

According to some Old Icelandic sources, sciopodes were to be found in northwestern Africa; indeed, the manuscript fragment from the turn of the fourteenth century (AM 736 I 4to) states that Vínland lies off this African coast. This information was copied into the Narfeyrarbók, the manuscript containing the itinerary Leiðarvísir (AM 194 8vo), which was also mentioned at the beginning of this article. ${ }^{79}$ This helps to explain the appearance of the einfæetingar in the contemporary Eiríks saga rauða (whereas their absence in the Grænlendinga saga might indicate that its author was not aware of this connection). Like the "skinpeople" skrælingar, they are relegated to the outskirts of the civilized world, with the other dark and violent masses of the periphery.

Having failed in their attempt to establish an outpost of Christian, European society in Vínland, the Grænlendinga saga concludes with a glimmer of redemption for the failed mission, not unlike that of Porvaldr víðforli. Upon her return from Vínland, Guðríðr Porbjarnardóttir makes a pilgrimage to Rome and then lives out her final years as a nun and hermit in Iceland: making her the most far-travelled or vífforla of them all, since her travels have stretched all the way from the wild West to the heart of the Christian East. The mission may have proved impossible, but there is still hope in individual salvation.

\section{Conclusion}

Narratives of the "historical" travels of the Norse to the West stand in stark contrast to their fictional travels to the East. In the latter, the true Christian faith is brought from the eastern periphery to the new centre of the narrative, Scandinavia, ${ }^{80}$ in order to show the domestication of Christianity within Norse society and revealing essential affinities between heroic Norse travellers and their Eastern European counterparts, before travels farther east bring them into contact with dangerous Oriental pagans. Travels westward illustrate the limitations of the Norse/Christian influence on this periphery, further emphasizing a kinship between Scandinavia and the cosmopolitan world of the Near East while demarcating the wider West as hostile and uncivilized.

Robert Kellogg once wondered how the Christianization of Iceland and the travels to America "came to be so closely connected in later traditions," concluding that it

78 “Eiríks saga rauða," 231-32.

79 Alfræði íslenzk I, 12.

80 On narrative centres, see Vídalín, The Supernatural in Íslendingasögur, 10-16. 
"is still something of a mystery."11 By comparing these two intertextual traditions, I have shown that there is, in fact, no mystery. At the heart of this tradition lies Óláfr Ormsson's Leiðarvísir, showing the path to the Holy Land through a world of horrible monsters derived from Pliny, which must be placed alongside contemporary sagas that orient Iceland to the East while Occidentalizing the monstrous races of the Americas. Travels to the East place Scandinavians within a rich European tradition stretching back to antiquity, making Iceland a cultural and religious outpost of that civilized world. Travels to colonize the West, partly to establish a new outpost of Christianity on that unexplored periphery, fail miserably. In travelling east, our heroes escape their pagan pasts and become missionaries of the true faith; when travelling west, they risk losing their tenuous grasp on the faith and their own identities. As Elizabeth Williamsen has eloquently remarked:

The fabled lands of bounty are elusive and deceptive ... Similarly, the necessary boundaries of difference created between the Norsemen and the skrælingarwho are inevitably equated with the land - engender hostility, contempt, and violence ... Because of the extreme and insurmountable otherness of Vínland, the Norsemen find it impossible to stay, and the sagas end with the heroes defeated, barred from Paradise by the boundaries they have constructed. ${ }^{82}$

While travels east might be described as Paradise regained, the westbound narratives centre on a Paradise lost.

In a cultural environment where the centre of Christianity is Jerusalem and the terrestrial Paradise is to the East, Iceland was a very remote place in the medieval Christian imaginary-if it figured in the imagination at all. In fact, it would have been easy for many contemporaries to assume that Iceland belonged to the monstrous margins of the world. Like Gerald of Wales, who wrote extensively about the marvels and monstrosities of Ireland in an attempt to centralize Britain while pushing Ireland westward to the periphery, ${ }^{83}$ Icelanders seem to have composed sagas about travels both east and west in order to bring Iceland closer to continental Europe and to relegate Vínland to the margins. Iceland thus edged comparatively close to Europe, with Greenland standing between the outermost Christian settlement and the monstrification of America's inhabitants. In travelling west, a new Occidental periphery is established and the vanguard of Christianity is redefined, at the expense of newly dehumanized Others.

8I Kellogg, “Vínland Sagas,” 31.

82 Williamsen, "Boundaries of Difference," 475-76.

83 Mittman, "The Other Close at Hand," 97-112. 


\section{Bibliography}

Alfræði íslenzk I. Edited by Kristian Kålund. Copenhagen: Møllers, 1908.

Almqvist, Bo. "My Name Is Guðríðr. What Is Your Name?" In Approaches to Vínland: A Conference on the Written and Archaeological Sources for the Norse Settlements in the North-Atlantic Region and Exploration of America, the Nordic House, Reykjavík 9-11 August 1999, edited by Andrew Wawn and Pórunn Sigurðardóttir, 15-30. Reykjavík: Sigurður Nordal Institute, 2001.

Antonsson, Haki. "Salvation and Early Saga Writing in Iceland: Aspects of the Works of the Pingeyrar Monks and Their Associates." Viking and Medieval Scandinavia 8 (2012): 71-140.

Arjana, Sophia Rose. Muslims in the Western Imagination. Oxford: Oxford University Press, 2015.

Augustine. The City of God. Translated by Eva M. Sanford and William M. Green, vol. 5: Books 16-18.35. Loeb Classical Library 415. Cambridge: Harvard University Press, 1965.

Biskupasögur I. Edited by Sigurgeir Steingrímsson, Ólafur Halldórsson, and Peter Foote. Reykjavík: Hið íslenzka fornritafélag, 2003.

Dinzelbacher, Peter. "Die mittelalterliche Allegorie der Lebensreise." In Monsters, Marvels and Miracles: Imaginary Journeys and Landscapes in the Middle Ages, edited by Leif Søndergaard and Rasmus Thorning Hansen, 65-112. Odense: University Press of Southern Denmark, 2005.

Duggals leiðsla. Edited by Peter Cahill. Reykjavík: Stofnun Árna Magnússonar, 1983.

“Eiríks saga rauða." In Eyrbyggja saga, Íslenzk fornrit no. 4, edited by Einar Ól. Sveinsson and Matthías Pórðarson. Reykjavík: Hið íslenzka fornritafélag, 1935.

"Eireks saga víðförla." In Fornaldarsögur Norðurlanda, edited by Guðni Jónsson and Bjarni Vilhjálmsson, vol. 3. Reykjavík: Bókaútgáfan Forni, 1944.

Eliav-Feldon, Miriam, Benjamin Isaac, and Joseph Ziegler, eds. The Origins of Racism in the West. Cambridge: Cambridge University Press, 2009.

Friedman, John Block. The Monstrous Races in Medieval Art and Thought. Syracuse: Syracuse University Press, 2000.

Gade, Finn. "Skrællinger." In Kulturhistorisk leksikon for nordisk middelalder fra vikingtid til reformationstid, edited by Lis Jacobsen and John Danstrup, vol. 15, 714-18. Copenhagen: Roskilde \& Bagger, 1981.

"Gríms saga loðinkinna." In Fornaldarsögur Norðurlanda, edited by Guðni Jónsson and Bjarni Vilhjálmsson, vol. 1. Reykjavík: Bókaútgáfan Forni, 1943.

"Grœnlendinga saga." In Eyrbyggja saga, Íslenzk fornrit no. 4, edited by Einar Ól. Sveinsson and Matthías Pórðarson, 241-69. Reykjavík: Hið íslenzka fornritafélag, 1935. 
Guðmundsdóttir, Soffía Guðný. “Uppdráttur af Jórsalaborg." In 66 handrit úr fórum Árna Magnússonar, edited by Svanhildur Óskarsdóttir, Matthew James Driscoll, and Sigurður Svavarsson, 96-97. Reykjavík: Den Arnamagnæanske Samling, Nordisk Forskningsinstitut/Stofnun Árna Magnússonar í íslenskum fræðum/ Bókaútgáfan Opna, 2013.

Halldórsson, Ólafur. "The Vínland Sagas." In Approaches to Vínland: A Conference on the Written and Archaeological Sources for the Norse Settlements in the North-Atlantic Region and Exploration of America, the Nordic House, Reykjavík 9-11 August 1999, edited by Andrew Wawn and Pórunn Sigurðardóttir, 39-51. Reykjavík: Sigurður Nordal Institute, 2001.

Hauksbók. Edited by Finnur Jónsson and Eiríkur Jónsson. Copenhagen: Det kongelige nordiske oldskrift-selskab, Thieles bogtrykkeri, 1892-96.

Heiniger, Anna Katharina. "On the Threshold: The Liminality of Doorways." In Paranormal Encounters in Iceland 1150-1400, edited by Ármann Jakobsson and Miriam Mayburd, 109-29. Berlin: de Gruyter 2020.

Heng, Geraldine. The Invention of Race in the European Middle Ages. Cambridge: Cambridge University Press, 2018.

[Honorius Augustodunensis]. Elucidarius in Old Norse Translation. Edited by Evelyn Scherabon Firchow. Reykjavík: Stofnun Árna Magnússonar, 1989.

Isaac, Benjamin. The Invention of Racism in Classical Antiquity. Princeton: Princeton University Press, 2004.

Isidore of Seville. The Etymologies of Isidore of Seville. Translated by Stephen A Barney, W. J. Lewis, J. A. Beach, and Oliver Berghof. Cambridge: Cambridge University Press, 2010.

Jakobsson, Ármann. "Íslenskir draugar frá landnámi til lúterstrúar: Inngangur að draugafræðum.” Skírnir 184 (2010): 187-210.

Jakobsson, Ármann, and Miriam Mayburd, eds. Paranormal Encounters in Iceland 1150-1400. Berlin: de Gruyter, 2020.

Jakobsson, Sverrir. "Black Men and Malignant-Looking: The Place of the Indigenous Peoples of North America in the Icelandic World View." In Approaches to Vínland: A Conference on the Written and Archaeological Sources for the Norse Settlements in the North-Atlantic Region and Exploration of America, the Nordic House, Reykjavík 9-11 August 1999, edited by Andrew Wawn and Pórunn Sigurðardóttir, 88-104. Reykjavík: Sigurður Nordal Institute, 2001.

_ . "On the Road to Paradise: 'Austrvegr' in the Icelandic Imagination." In The Fantastic in Old Norse/Icelandic Literature: Sagas and the British Isles, edited by John McKinnell, David Ashurst, and Donata Kick, 925-43. Durham: Centre for Medieval and Renaissance Studies, Durham University, 2006. 
Jensson, Gottskálk. "Were the Earliest Fornaldarsögur Written in Latin?" In Fornaldarsagaerne: Myter og Virkilighed, edited by Agneta Ney, Ármann Jakobsson, and Annette Lassen, 79-92. Copenhagen: Museum Tusculanums Forlag, 2009.

Jochens, Jenny. “The Western Voyages: Women and Vikings." In Approaches to Vínland: A Conference on the Written and Archaeological Sources for the Norse Settlements in the North-Atlantic Region and Exploration of America, the Nordic House, Reykjavík 9-11 August 1999, edited by Andrew Wawn and Pórunn Sigurðardóttir, 78-87. Reykjavík: Sigurður Nordal Institute, 2001.

Kedwards, Dale. The Mappae Mundi of Medieval Iceland. Woodbridge: Boydell, 2020. Kellogg, Robert. "The Vínland Sagas: A Romance of Conversion." In Approaches to Vínland: A Conference on the Written and Archaeological Sources for the Norse Settlements in the North-Atlantic Region and Exploration of America, the Nordic House, Reykjavík 9-11 August 1999, edited by Andrew Wawn and Pórunn Sigurðardóttir, 31-38. Reykjavík: Sigurður Nordal Institute, 2001.

“Ketils saga hœngs." In Fornaldarsögur Norðurlanda, edited by Guðni Jónsson and Bjarni Vilhjálmsson, vol. 1. Reykjavík: Bókaútgáfan Forni, 1943.

Kline, Naomi Reed. Maps of Medieval Thought: The Hereford Paradigm. Hockley: Boydell, 2001.

Konungs skuggsiá. Edited by Ludvig Holm-Olsen, Norrøne tekster no. 1. Oslo: Norsk historisk kjeldeskrift-institutt, 1983.

Kristjánsson, Jónas. "Falling into Vínland: Newfoundland Hunting Pitfalls at the Edge of the Viking World." In Sagnalíf: Sextán greinar um fornar bókmenntir, edited by Pórður Ingi Guðjónsson, 354-404. Reykjavík: Stofnun Árna Magnússonar í íslenskum fræðum, 2015.

"Landnámabók." In Íslendingabók/Landnámabók, edited by Jakob Benediktsson. Reykjavík: Hið íslenzka fornritafélag, 1986.

Larrington, Carolyne. “'Undruðusk pá, sem fyrir var': Wonder, Vínland and Mediaeval Travel Narratives.” Mediaeval Scandinavia 14 (2004): 91-114.

Lönnroth, Lars. "From History to Myth: The Ingvar Stones and Yngvars saga viðforla." In Nordic Mythologies: Interpretations, Intersections, and Institutions, edited by Timothy R. Rangherlini, 100-114. Berkeley: North Pinehurst, 2014.

—. "A Road Paved with Legends." In Two Norse-Icelandic Studies: Sponsors, Writers and Readers of Early Norse Literature and A Road Paved with Legends. Gothenburg: Göteborgs Universitet, Litteraturvetenskapliga Institutionen, 1990.

Mallon, Ron. The Construction of Human Kinds. Oxford: Oxford University Press, 2016.

Mandevilles rejse. Edited by M. Lorentzen. Copenhagen: Møllers, 1882. 
Marani, Tomasso. "Leiðarvísir: Its Genre and Sources, with Particular Reference to the Description of Rome." Unpublished PhD diss., Durham University, 2013. http://etheses.dur.ac.uk/6397/.

Merkelbach, Rebecca, and Gwendolyne Knight, eds. Margins, Monsters, Deviants: Alterities in Old Norse Literature and Culture. Turnhout: Brepols, 2020.

Mittman, Asa Simon. "The Other Close at Hand: Gerald of Wales and the Marvels of the West." In The Monstrous Middle Ages, edited by Bettina Bildhauer and Robert Mills, 97-112. Toronto: University of Toronto Press, 2003.

Morkinskinna, vol. 2. Edited by Ármann Jakobsson and Pórður Ingi Guðjónsson. Reykjavík: Hið íslenzka fornritafélag, 2011.

“Örvar-Odds saga." In Fornaldarsögur Norðurlanda, edited by Guðni Jónsson and Bjarni Vilhjálmsson, vol. 1. Reykjavík: Bókaútgáfan Forni, 1943.

Pálsson, Hermann. Úr landnorðri: Samar og ystu rætur íslenskrar menningar. Studia Islandica 54. Reykjavík: Bókmenntafræðistofnun Háskóla Íslands, 1997.

Quinn, Judy, Marianne E. Kalinke, Margaret Clunies Ross, Carl Phelpstead, Torfi H. Tulinius, Gottskálk Jensson, Ármann Jakobsson, Annette Lassen, Elizabeth Ashman Rowe, Stephen A. Mitchell, Aðalheiður Guðmundsdóttir, Ralph O'Connor, and Matthew Driscoll. "Interrogating Genre in the Fornaldarsögur: Round-Table Discussion." Viking and Medieval Scandinavia 2 (2006): 275-96.

Rowe, Elizabeth Ashman. The Development of Flateyjarbók: Iceland and the Norwegian Dynastic Crisis of 1389, The Viking Collection 15. Odense: The University Press of Southern Denmark, 2005.

Russell, Jeffrey Burton. Lucifer: The Devil in the Middle Ages. Ithaca: Cornell University Press, 1984.

Schulz, Katja. Riesen: Von Wissenshütern und Wildnisbewohnern in Edda und Saga. Heidelberg: Universitätsverlag Winter, 2004.

Sigurðsson, Gísli. Túlkun Íslendingasagna í ljósi munnlegrar hefðar: Tilgáta um aðferð. Reykjavík: Háskólaútgáfan, 2002.

Simek, Rudolf. Altnordische Kosmographie: Studien und Quellen zu Weltbild und Weltbeschreibung in Norwegen und Island vom 12. bis zum 14. Jahrhundert. Berlin: de Gruyter, 1990.

—. "Scandinavian World Maps." In Trade, Travel, and Exploration in the Middle Ages: An Encyclopedia, edited by John Block Friedman and Kristen Mossler Figg, with Scott D. Westrem and Gregory G. Guzman, 537-38. New York: Garland, 2000.

Smith, Jonathan Livingstone. Less than Human: Why We Demean, Enslave, and Exterminate Others. New York: St. Martin's, 2011.

Stjórn. Edited by Reidar Astås, vol. 1. Norrøne Tekster 8. Oslo: Riksarkivet, 2009. 
Strickland, Debra. "The Sartorial Monsters of Herzog Ernst." Different Visions: A Journal of New Perspectives on Medieval Art 2 (2010): 130-64.

Thalbitzer, William. Fra Grønlandsforskningens første dage. Copenhagen: Bianco Luno, 1932.

Tómasson, Sverrir. “Ferðir pessa heims og annars: Paradís-Ódáinsakur-Vínland í íslenskum ferðalýsingum miðalda." Gripla 12 (2001): 23-40.

Vídalín, Arngrímur. "Demons, Muslims, Wrestling-Champions: The Semantic History of Blámenn from the 12th to the 20th Century." In Paranormal Encounters in Iceland 1150-1400, edited by Ármann Jakobsson and Miriam Mayburd, 203-26. Berlin: de Gruyter, 2020.

—_. "Er pat illt, at pú vilt elska troll pat: Hið sögulega samhengi jöðrunar í Hrafnistumannasögum." Gripla 24 (2013): 173-210.

—. "From the Inside Out: Chronicles, Genealogies, Monsters, and the Makings of an Icelandic World View." In Supernatural Encounters in Old Norse Literature and Tradition, edited by Daniel Sävborg and Karen Bek-Pedersen, 143-74. Turnhout: Brepols, 2018.

—. "Ideals of Christian Kingship: The Implications of Elucidarius, Konungs skuggsiá, and Eiríks saga víðforla." In Aspects of Royal Power in Medieval Scandinavia, edited by Jakub Morawiec and Rafał Borysławski, 129-38. Katowice: Wydawnictwo Uniwersytetu Śląskiego, 2018.

—. "The Man Who Seemed Like a Troll: Racism in Old Norse Literature." In Margins, Monsters, Deviants: Alterities in Old Norse Literature and Culture, edited by Rebecca Merkelbach and Gwendolyne Knight, 215-38. Turnhout: Brepols, 2020.

—. “Óláfr Ormsson's Leiðarvísir: The 14th Century Text of a Supposed 12th Century Itinerary." Journal of English and Germanic Philology 117 (2018): 212-34.

—. Skuggsjá sjálfsins: Skrímsl, jöðrun og afmennskun í lærdómshefð íslenskra sagnaritara 1100-1550. Reykjavík: Hugvísindasvið Háskóla Íslands, 2017.

—. The Supernatural in Íslendingasögur: A Theoretical Approach to Definition and Analysis. Reykjavík: Tower, 2012.

"Völsunga saga." In Fornaldarsögur Norðurlanda, edited by Guðni Jónsson and Bjarni Vilhjálmsson, vol. 1, 1-91. Reykjavík: Bókaútgáfan Forni, 1943.

The Voyage of Saint Brendan. Edited by John J. O’Meara. Gerrards Cross: Colin Smythe, 1991.

Wellendorf, Jonas. Kristelig visionslitteratur i norrøn tradition. Oslo: Novus, 2009.

Williamsen, E. A. "Boundaries of Difference." Scandinavian Studies 77 (2005): 451-78. 
"Yngvars saga víðförla." In Fornaldarsögur Norðurlanda, edited by Guðni Jónsson and Bjarni Vilhjálmsson, vol. 3. Reykjavík: Bókaútgáfan Forni, 1944.

Zumthor, Paul. "The Medieval Travel Narrative." New Literary History 25 (1994): 809-24.

porláksson, Helgi. "The Vínland Sagas in a Contemporary Light." In Approaches to Vínland: A Conference on the Written and Archaeological Sources for the Norse Settlements in the North-Atlantic Region and Exploration of America, the Nordic House, Reykjavík 9-11 August 1999, edited by Andrew Wawn and Pórunn Sigurðardóttir, 63-77. Reykjavík: Sigurður Nordal Institute, 2001.

"Porvalds páttr víðfǫrla I-II." In Biskupasögur I, edited by Sigurgeir Steingrímsson, Ólafur Halldórsson, and Peter Foote. Reykjavík: Hið íslenzka fornritafélag, 2003. 
Arngrímur Vídalín (arngrimurv@hi.is) is adjunct professor of Icelandic literature at the University of Iceland's School of Education. He holds a PhD in Old Norse literature from the University of Iceland (2017) and a Cand. Mag. (MA) in Nordic languages and literature from Aarhus University, Denmark (2012). His work focuses on the learned literature of medieval Europe, as well as dehumanization and the supernatural in medieval literature.

Abstract This article analyses five fourteenth-century Old Norse travel narratives in light of the learned geographical tradition of medieval Iceland. Three of the narratives, Porvalds páttr víðforla, Eiríks saga víðforla, and Yngvars saga víðforla, focus on the travels of Nordic people to eastern Europe and Asia; while the latter two, Eiríks saga rauða and Gronlendinga saga, tell of travels to the continent later named North America. While the travels to the East deal with pilgrimage and the search for the terrestrial Paradise in the service of individual salvation and missionary activities in Scandinavia and Iceland more specifically, the travels to the West are focused on the violent conquest and Christianization of newfound peripheral areas and their peoples. What these narratives have in common, and owe to the learned (Plinian) tradition, is their dehumanized view of foreign and strange people: the giants and monsters of the East, and the skrælingar (indigenous peoples) and einfoetingar (sciopods) of the West. In these sagas travels to the East, while dangerous, introduce heroes to courtly manners, encyclopedic knowledge, and salvation; whereas travels to the West lead to mayhem and death and all attempts at settlement there fail miserably, making Greenland the westernmost outpost of Christianity in the world. This article aims to show how this learned tradition was adapted for use in saga literature to contrast the monstrous and heathen periphery with the more central and piously Christian Iceland.

Keywords Old Norse, travel literature, pilgrimage, Vínland, dehumanization, race, alterity, proto-racism, Christianization, centre vs. periphery. 